\title{
Task 4 - Conversion to a Coal-Fueled Advanced Turbine System (CFATS)
}

\section{Topical Report April 15, 1996}

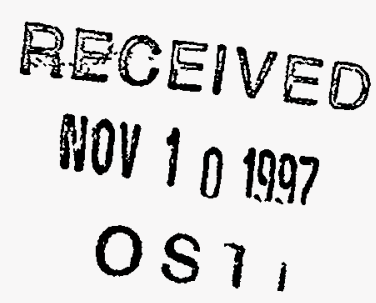

Work Performed Under Contract No.: DE-AC21-93MC30246

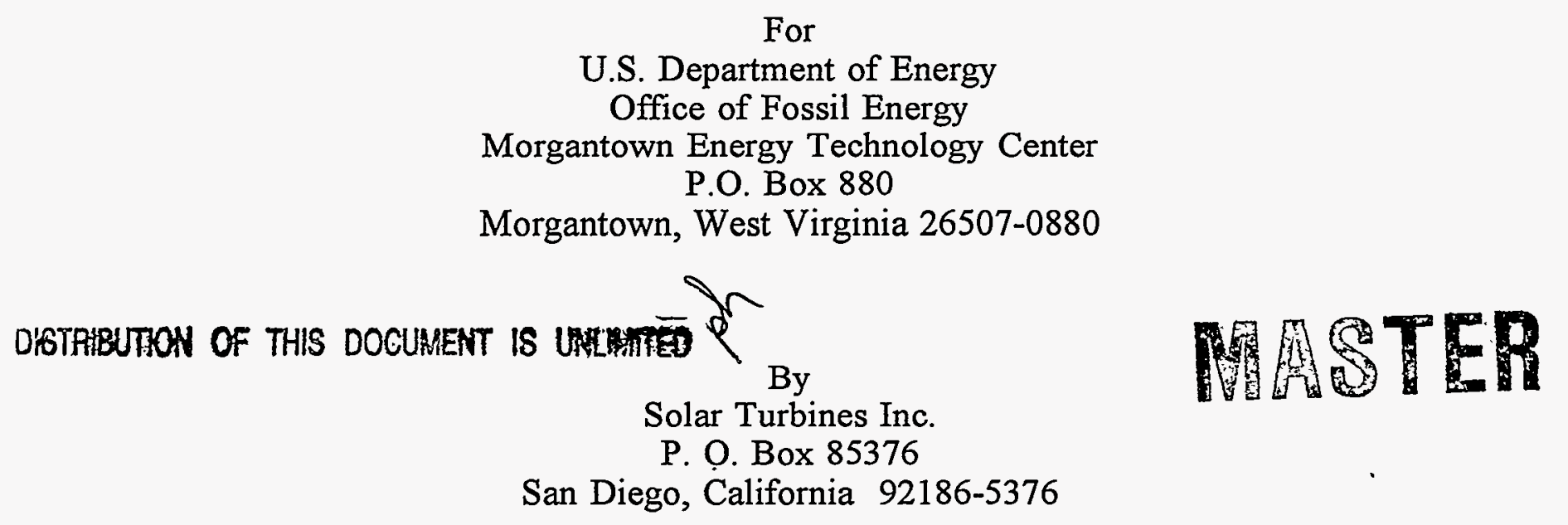




\section{Disclaimer}

This report was prepared as an account of work sponsored by an agency of the United States Government. Neither the United States Government nor any agency thereof, nor any of their employees, makes any warranty, express or implied, or assumes any legal liability or responsibility for the accuracy, completeness, or usefulness of any information, apparatus, product, or process disclosed, or represents that its use would not infringe privately owned rights. Reference herein to any specific commercial product, process, or service by trade name, trademark, manufacturer, or otherwise does not necessarily constitute or imply its endorsement, recommendation, or favoring by the United States Government or any agency thereof. The views and opinions of authors expressed herein do not necessarily state or reflect those of the United States Government or any agency thereof. 


\section{DISCLAIMER}

Portions of this document may be illegible in electronic image products. Images are produced from the best available original document. 


\section{CONTENTS}

Paragraph

Page

OVERVIEW

1

1

GENERAL APPROACH

2

2

DISCUSSION

3

2.1 Direct Fired Systems

2.1.1 Coal-Water Slurry

2.1.2 Dry Coal

3

2.1.3 Pressurized Fluidized Bed Combustion Systems (PFBC)

2.2 Indirect or Externally Fired Systems (EFS)

2.3 Gasification

3.1 Conclusions

3.2 Recommendations 


\section{FIGURES}

Figure

Page

1

System Description .

3

2

Full Size Centaur Coal Combustor

4

\section{TABLES}

Table

Page

1

Combustor Operating Conditions

4

2

Gasification Reactions and Kinetic Constants

7

3

Typical Biomass and Coal Derived Gaseous Fuels

8 


\section{OVERVIEW}

Solar is developing the technologies for a highly efficient, recuperated, Advanced Turbine System (ATS) that is aimed at the dispersed power generation market. With ultra-low-emissions in mind the primary fuel selected for this engine system is natural gas. Although this gas fired ATS (GFATS) will primarily employ natural gas the use of other fuels particularly those derived from coal and renewable resources cannot be overlooked. The enabling technologies necessary to direct fire coal in gas turbines were developed during the 1980's. This Solar development co-sponsored by the U.S. Department of Energy (DOE) resulted in the testing of a full size coal-water-slurry fired combustion system. In parallel with this program the DOE funded the development of integrated gasification combined cycle systems (IGCC). This report describes the limitations of the Solar ATS (recuperated engine) and how these lead to a recommended series of modifications that will allow the use of these alternate fuels.

Three approaches have been considered: direct-fired combustion using either a slagging combustor, or a pressurized fluidized bed (PFBC), externally or indirectly fired approaches using pulverized fuel, and extemal gasification of the fuel with subsequent direct combustion of the secondary fuel. Each of these approaches requires substantial hardware and system modifications for efficient fuel utilization. The integration issues are discussed in the sections below and a recommended approach for gasification is presented. 


\section{SECTION 1.0}

\section{GENERAL APPROACH}

A 5-MW ATS will be used throughout this report for discussion purposes. This engine incorporates a recuperator and possibly a catalytic combustor. The significance of the recuperator for the purposes of conversion to coal firing is that the engine will use external ducting to take the air from the compressor section to the recuperator and then back from the recuperator to the turbine section. This external ducting provides great flexibility allowing large stand-alone combustion schemes or externally fired heat exchange systems to be connected in place of the catalytic combustor. Although the engine can be readily adapted, there are likely to be some materials of construction problems with the ducting that leads to the turbine section because of the high temperatures and corrosiveness of the combustion products.

External gasification of coal and biomass materials produces secondary fuels that consist primarily of carbon monoxide $(\mathrm{CO})$, hydrogen $\left(\mathrm{H}_{2}\right)$, carbon dioxide $\left(\mathrm{CO}_{2}\right)$, and nitrogen $\left(\mathrm{N}_{2}\right)$. Catalytic combustors can be used to combust these gases produced from coal or biomass materials however they would require the use of a different catalytic material composition than that needed for natural gas (methane). In some cases (particularly those gases with low heating values) a catalytic combustor would not be required and would be replaced by a more conventional turbine combustor. Solar has accumulated considerable experience in the handling and combustion of both biomass derived gases, gob gases, and landfill gases. These gases cover the range of constituents and heating values likely to be found in practice. 


\section{SECTION 2.0}

\section{DISCUSSION}

There are at least three approaches to burning coal or biomass derived fuels in a gas turbine engine. These approaches include direct-firing, indirect firing, and gasification, where the base fuel is converted to a low to medium Btu gaseous fuel in an external reactor. During the 1980's the DOE sponsored work to develop methods to direct fire coal in gas turbines either as a slurry with water or as a dry powder. Each of these approaches are described in detail in the sections that follow.

\subsection{DIRECT FIRED SYSTEMS}

\subsubsection{Coal-Water Slurry}

At Solar the development of direct firing of a gas turbine with coal water slurry (CWS) was pursued under the aegis of a cost shared DOE contract. The system chosen shown in Figure 1 included a rich primary zone and a lean secondary combustor zone. The combustor for a 4-MW engine is shown in Figure 2 without the hot gas cleanup filter (HGCF). The slag produced by the ash in the coal was aerodynamically removed in the primary zone and in a component between the primary and secondary called the particulate removal impact separator (PRIS). This latter component consisted of staggered rows of rods which served to create a series of orifices and particle impaction sites. Much of this design was based on previous

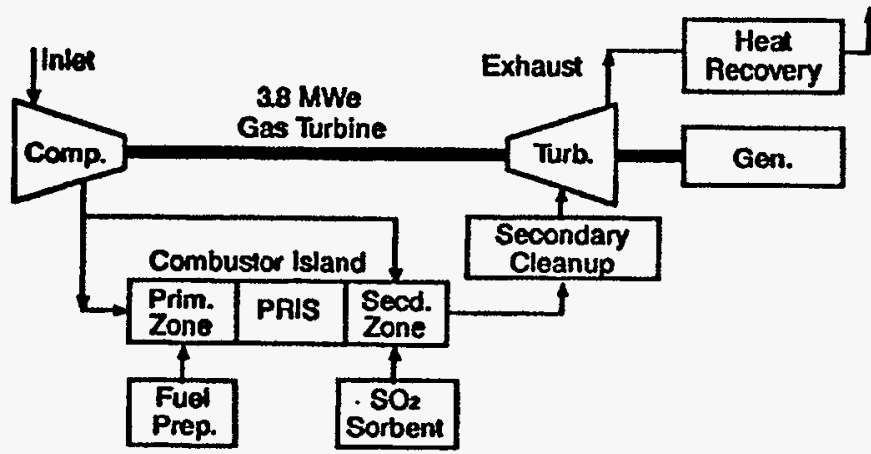

Figure 1. System Description work done for DOE's Pittsburgh Energy Technology Center. Between the primary zone and the PRIS over 90 percent of the slag was removed. The primary zone design equivalence ratio was approximately 1.3 which resulted in NOx results as low as 30 ppmv corrected to 15 percent oxygen. The system was designed for the Solar Centaur 50 engine which has a combustor inlet temperature of $606^{\circ} \mathrm{K}\left(630^{\circ} \mathrm{F}\right)$. The cycle data for the Centaur 50 and the ATS are listed in Table 1. For the data in Table 1 the primary zone outlet temperature, (the inlet temperature to the PRIS) was $1760-1870^{\circ} \mathrm{K}\left(2700-2900^{\circ} \mathrm{F}\right)$. Material problems with the PRIS rods were encountered but not resolved before the program was terminated. In cases where the sulfur in the coal would result in higher $\mathrm{SO}_{2}$ emissions than allowed it was planned to inject a calciumbased sorbent such as dolomite into the secondary zone, which allows capture of the sulfur as a particulate. To remove the remaining slag and the particulate produced by the addition of the sorbent a high temperature barrier filter was designed to be installed after the secondary zone and before the turbine of the engine. 
Table 1. Combustor Operating Conditions

\begin{tabular}{||l|l|l||}
\hline Parameter & Centaur 50 & ATS \\
\hline Air flow, kg/sec (pps) & $18.6(41)$ & $15(33)$ \\
\hline Inlet Temperature, ${ }^{\circ} \mathrm{K}\left({ }^{\circ} \mathrm{F}\right)$ & $606(632)$ & $874(1114)$ \\
\hline Outlet Temperature, ${ }^{\circ} \mathrm{K}\left({ }^{\circ} \mathrm{F}\right)$ & $1284(1851)$ & $1481(2206)$ \\
\hline Inlet Pressure, $\mathrm{kPa}(\mathrm{psia})$ & $1046(151.6)$ & $869(125.9)$ \\
\hline
\end{tabular}

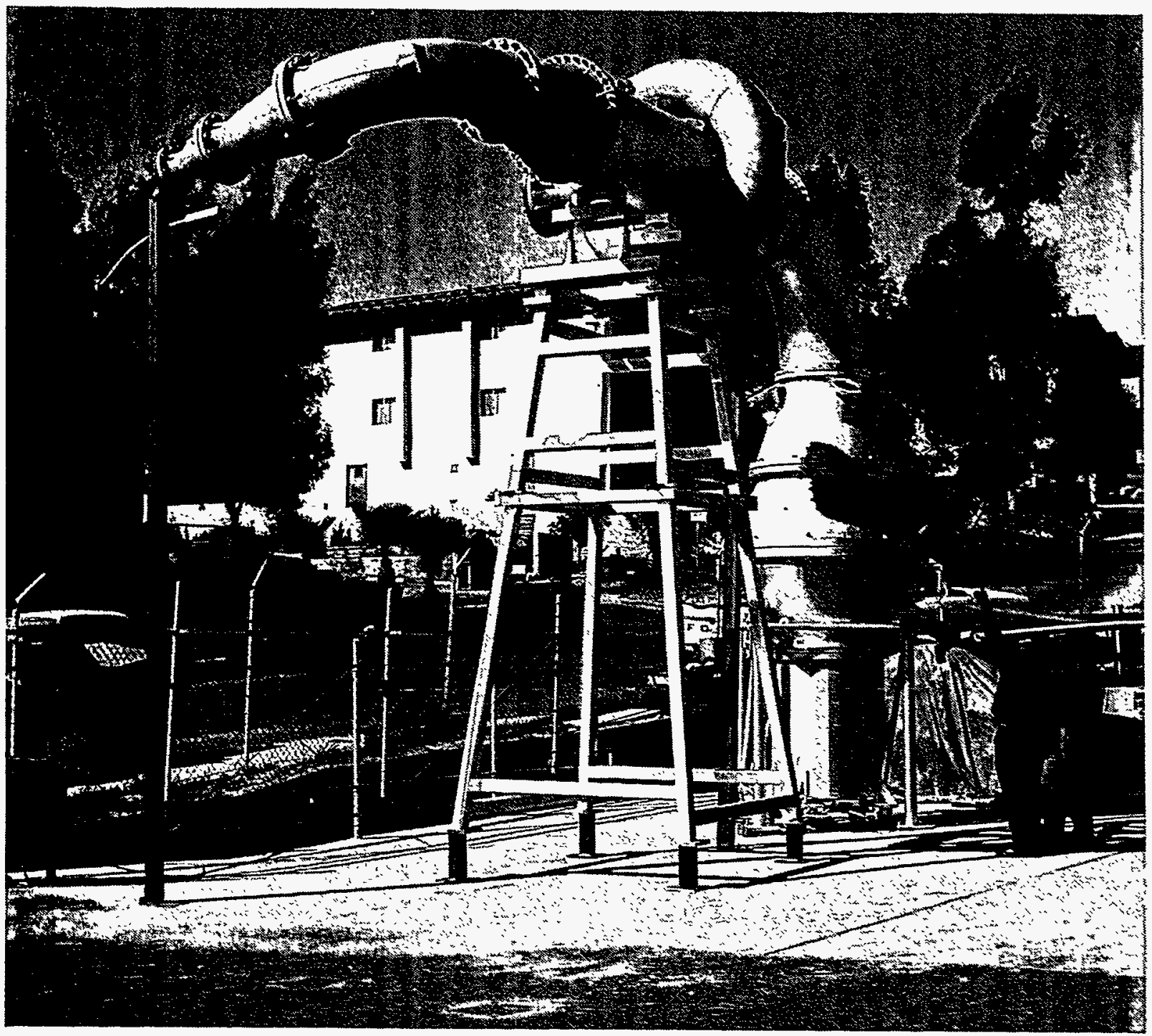

Figure 2. Full Size Centaur Coal Combustor 
Since the cycle chosen for the ATS engine includes a recuperator the combustor inlet temperature will be high on the order of $870^{\circ} \mathrm{K}\left(1100^{\circ} \mathrm{F}\right)$. This high inlet temperature will be reflected in a high combustor primary zone temperature that would be in the range of $3440-3640^{\circ} \mathrm{K}\left(3170-3370^{\circ} \mathrm{F}\right)$. This increase in temperature would make the PRIS rod material problem worse. An increase in primary zone equivalence ratio would decrease the primary zone outlet temperature but ultimately result in higher NOx levels. At this time the NOx limits for an engine burning coal or biomass-derived fuels are not known but it is unlikely that a direct-fired cycle would meet the NOx goals of the ATS program.

In addition to high levels of NOx there is the problem of particulate blocking of the very small gas passages of the recuperator. None of the hot gas particulate removal systems developed to date remove all of the suspended material. Some of the particulates will pass through the combined removal devices and potentially will block the recuperator.

\subsubsection{Dry Coal}

Some work was done to examine the possibility of direct-firing dry coal in powder form during the same DOE program. The problems from a combustion standpoint include the increase in primary zone temperature when water injection is not used. This higher temperature in turn increases the $\mathrm{NO}_{\mathrm{x}}$ production levels and the severity of the material problems discussed above. The use of dry powdered coal involves extra fuel handling equipment and the uncertainties concerning whether the equivalence ratio for the dry coal can be increased sufficiently to lower the primary zone temperature to the point where low NOx levels can be obtained. As with the coal water slurry fired systems there will also be potential recuperator blocking problems. Because of the likely higher cycle temperatures these recuperator blocking problems will be more severe than with water slurries. With a recuperated ATS cycle direct-firing of coal in a rich-lean combustor does not appear to be a viable approach to converting the GFATS into a coal fired ATS (CFATS).

\subsubsection{Pressurized Fluidized Bed Combustion Systems (PFBC)}

PFBC systems are large combustion systems that hold coal or biomass particles in suspension until they combust. In the case of coal this is an effective approach both in terms of combustion and for the sorption of sulfur compounds by dolomite based powders. The sorbants can be intimately mixed with the combusting coal. Fluidized beds when pressurized have sealing problems in the fuel feed areas and also in the ash removal systems. Agglomeration problems are also present if the ash softening temperatures are exceeded. Particulate carryover from the fluidized bed to the recuperator is again a major potential problem and this will be found with any direct firing approach.

\subsection{INDIRECT OR EXTERNALLY FIRED SYSTEMS (EFS)}

A second approach to the use of coal and biomass fuels in a gas turbine is the externally-fired combustor. Using this technique the solid fuel is burned in an atmospheric combustor system. The exhaust leaving this combustor is passed through a heat exchanger before being exhausted to ambient. The stream to be heated in the heat exchanger by the exhaust is the air from the discharge of the gas turbine compressor. This air after heating is delivered to the turbine inlet section. Since the ATS engine already incorporates a recuperator external ducting to and from the main engine exists. In this particular instance the recuperator would be replaced with the heat exchanger section of the EFS using modified external ducting. In this system the exhaust of the combustor is separated from the turbine so that none of the potential contaminants and particulates pass through the turbine thus solving some of the corrosion and deposition problems. There are, however numerous other problems with this approach for the turbine. To heat the air to the desired turbine 
inlet temperature of approximately $1481^{\circ} \mathrm{K}\left(2206^{\circ} \mathrm{F}\right)$ the heat exchanger materials of construction must be capable of operating at slightly higher temperatures. There are few metallic materials which can stand these temperatures without cooling. Because of the large surface areas that would have to be cooled the air flows involved are large. The air flow requirements for cooling would be so high that the efficiency of the engine would be severely degraded. There has been some work to develop ceramic heat exchangers and these would fulfill the requirements of an externally fired gas turbine system. As yet these systems are not commercially available and may not be for many years to come.

Another problem area involves the operating procedures. The start sequence will probably require a conventionally fueled combustor arranged in parallel with the external unit to supply the necessary energy to start and accelerate the turbine while the external heat exchanger is brought up to temperature. With such an arrangement hot gas valving would be needed to control the air flow path during the changeover from one combustor to the other. During normal gas turbine operation the power output usually has to be regulated to follow load demands. These load changes often occur rapidly thus demanding a rapid response from the engine. If control of the fuel flow to the external combustor is used to vary the output power level there will be too long a time lag because of the thermal hysteresis inherent in the heat exchanger. One possible strategy that minimizes the time lag is to by-pass some of the air around the heat exchanger to handle the off-loads. On-loads or increasing loads are a different story and probably will require the use of the conventionally fueled start-up combustor. The control problems are not insurmountable particularly in this age of microprocessor controlled systems however the hot gas valving required is unlikely to be developed in the near future. These valves because of the operating temperatures will be constrained to use as materials of construction ceramics or similar materials.

The constraints noted above essentially remove the EFS from consideration as a possible approach to use solid fuels such as coal and biomass in an ATS. Developments in ceramic heat exchangers and valving may, in the future, make this technique possible.

\subsection{GASIFICATION}

There are many processes available that can be used to gasify both coal and biomass. Many of these processes have been in use for a number of years. Generally the gasification processes consist of either pyrolysis alone or pyrolysis combined with some form of char gasification. The char, always produced when coals or biomass are pyrolysed, can be converted to gases through reaction with steam and/or oxygen. The reaction with steam is endothermic while that with oxygen is exothermic. There are many chemical reactions that can take place in a gasifier (see Table 2) however the three main reactions of the solid fuel are: pyrolysis or devolatilization, gasification, and combustion. Gas phase reactions such as the water-gas shift reactions and methanation reactions can also take place. In most gasifiers the thermal energy required to gasify the solid fuel is supplied by the combustion or partial combustion of part of this fuel. When these two reactions are thermally balanced the gasifier can produce high levels of hydrogen and carbon monoxide. The lower heating value of the secondary gaseous fuel produced depends largely on whether air or oxygen is used as the oxidizer in the combustion process. When air is used for (partial) oxidation and cracking the product is usually a low energy gas (LEG) because the nitrogen in the air acts as a diluent. Pure oxygen blown approaches produce medium energy (MEG) gases. Increased local temperatures when oxygen is used can boost the char gasification rates. This latter reaction dilutes the product gas by introducing carbon dioxide. 
Table 2. Gasification Reactions and Kinetic Constants

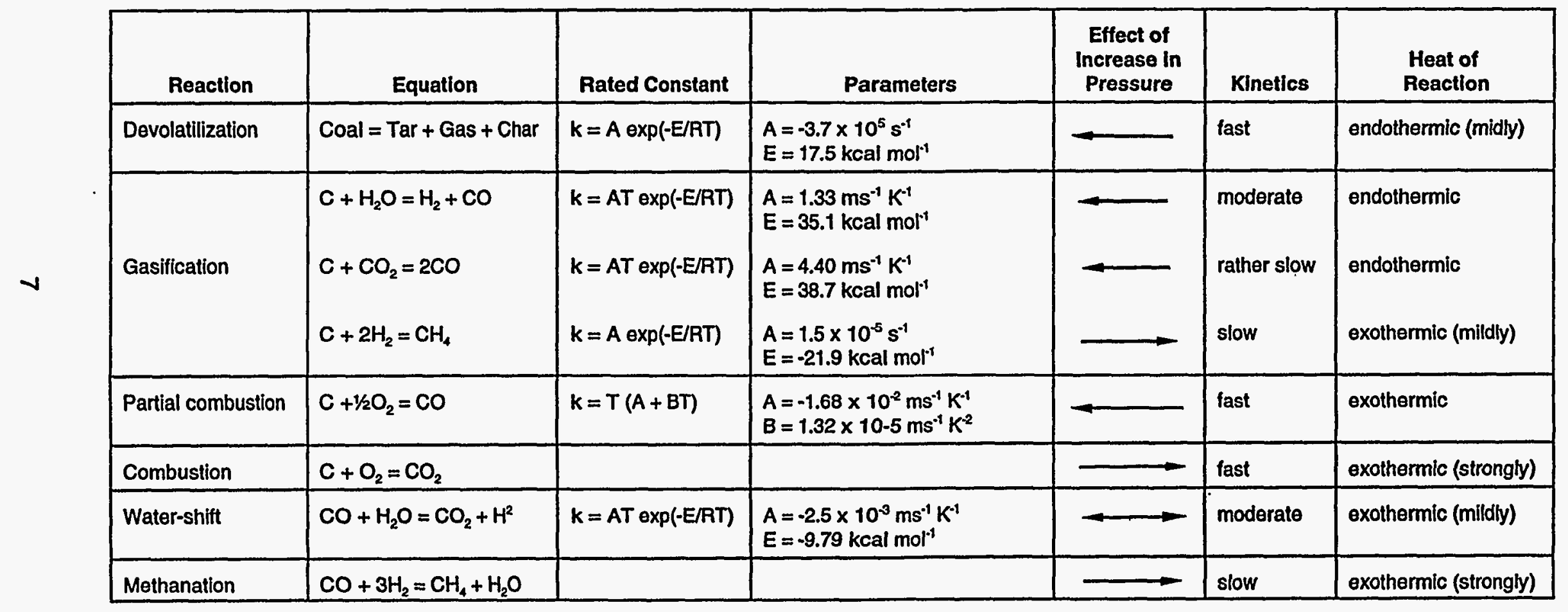


Other gasification approaches include hydrogasification. This technique employs pyrolysis of the primary fuel in an atmosphere of hydrogen or in a mixture of steam and hydrogen. This type of gasification can produce a product gas with high levels of hydrocarbons and this usually provides the highest lower heating values.

In most cases the infrastructure required for these reactors is such that it does not make economic sense to provide one reactor for a single 5-MW turbine. To consider these gases as viable fuels for the ATS a supply of gas from a central reactor would have to be assured. Table 3 lists some typical gases which can be produced from coal and biomass materials along with the parameters that are important in assessing their suitability for use in a gas turbine.

Table 3. Typical Biomass and Coal Derived Gaseous fuels

\begin{tabular}{||l|l|l|l|l||}
\hline TYPE & $\begin{array}{l}\text { LHV } \\
\text { Btu/scf }\end{array}$ & $\begin{array}{l}\text { Wobbe } \\
\text { Index }\end{array}$ & Constituents & $\begin{array}{l}\text { Flame } \\
\text { Temp }{ }^{\circ} \mathrm{F}\end{array}$ \\
\hline Coal Gas Air Blown & 133 & 143 & $\mathrm{H}_{2}, \mathrm{CH}_{4}, \mathrm{~N}_{2}, \mathrm{CO}, \mathrm{CO}_{2}$ & 3277 \\
\hline TCl Reactor & 306 & 396 & $\mathrm{H}_{2}, \mathrm{CH}_{4}, \mathrm{C}_{2} \mathrm{H}_{6}, \mathrm{CO}_{1} \mathrm{CO}_{2}$ & 3949 \\
\hline Coal Gas Oxygen Blown & 312 & 363 & $\mathrm{H}_{2}, \mathrm{CH}_{4}, \mathrm{~N}_{2}, \mathrm{CO}, \mathrm{CO}_{2}$ & 4097 \\
\hline Landfill Gas minimum & 363 & 358 & $\mathrm{CH}_{4}, \mathrm{CO}_{2}, \mathrm{AlR}$ & 4001 \\
\hline Battelle Gasifier & 367 & 411 & $\mathrm{H}_{2}, \mathrm{CH}_{4}, \mathrm{C}_{2} \mathrm{H}_{6}, \mathrm{~N}_{2}, \mathrm{CO}_{1} \mathrm{CO}_{2}$ & 4062 \\
\hline Gob Gas & 454 & 515 & $\mathrm{CH}_{4}, \mathrm{AlR}^{2}$ & 3999 \\
\hline Landfill Gas maximum & 485 & 486 & $\mathrm{H}_{2}, \mathrm{CH}_{4}, \mathrm{~N}_{2}, \mathrm{CO}_{2}, \mathrm{O}_{2}$ & 3626 \\
\hline Digester Gas & 590 & 624 & $\mathrm{Methane}_{2} \mathrm{CO}_{2}$ & 3756 \\
\hline Sales Gas & 937 & 1214 & $\mathrm{CH}_{4}, \mathrm{C}_{2} \mathrm{H}_{6}, \mathrm{C}_{3} \mathrm{H}_{8}, \mathrm{~N}_{2}, \mathrm{CO}_{2}$ & 4006 \\
\hline
\end{tabular}

Many of these fuels are in use today in Solar gas turbines using conventional combustors with modifications to the fuel handling components to accommodate the increased volume flow. It should be recognized that there has been no attempt to date to develop biomass gasification systems that are integrated directly with a gas turbine.

To select a particular process that could handle either coal and/or biomass and produce a gas that is suitable for a gas turbine is difficult with the data available today. Thus, we have separated the processes into those developed specifically for coal and those developed for biomass. This then allows the selection of well documented gasifiers for use in analyses.

For the gasification of coal we considered the pressurized oxygen and steam blown gasifiers typified by the Lurgi and the Koppers-Totzek processes to be the best systems for a recuperated engine. These pressurized gasifiers produce a MEG ideally suitable for use in gas turbines. Minimal modifications are needed to the engine to burn such a fuel and no gas compression equipment is needed. The main reason for choosing a MEG gasifier over the less expensive LEG gasifiers is that the recuperator pressure loss will be lower for the MEG than the LEG. As the mass flow of the 
engine is increased, to accommodate fuels with lower heating values that are considerably below that of natural gas, the recuperator pressure loss increases. This pressure loss directly affects the engine efficiency. To minimize first costs the recuperator for the natural gas fired ATS will be designed for the maximum allowable pressure losses commensurate with the desired system efficiency. Any increase in this pressure loss will be reflected in either lower efficiencies or lower power levels or both.

The main engine problem with these gasifiers will be one of emissions exacerbated by the nitrogen and sulfur compounds likely to be present in the fuel gas. This will probably drive the combustor to be a rich-lean type of system. To mitigate the likely turbine vane and blade sulfidation problems, recently developed silicon doped aluminide coatings could be used. Generally the problems associated with the use of secondary fuels derived from coal are readily solved through the use of existing technologies. There is an economic problem with the Lurgi type processes which is associated with the need to supply oxygen as a feedstock. Oxygen can be extracted from air by cryogenic approaches or by membrane separation techniques, if pure oxygen is not required. The trend is toward the use of inexpensive membrane separation systems to supply oxygen enriched air for gasification processes. This produces a MEG with a slightly lower heating value because of the diluent effects of the nitrogen from the air however the cost of the gas is substantially lower than that produced with pure oxygen.

Gasification of biomass has not as yet entered the phase of widespread adoption except in the case of the air blown downdraft gasifiers of the Hesselman and Imbert types. These latter gasifiers were popular during World War II and were produced In large numbers in Sweden and Germany respectively. There have been several derivative systems developed since that time and many are still in use in developing countries. These gasifiers were developed primarily for use with automotive engines and the suction stroke provided the means for drawing air through the gasifier. These gas fired engines can be used to power automobiles or electrical generators.

Preferably, the gasifiers to be integrated with gas turbines, should be pressurized. However, there are few biomass gasifiers that are pressurized much above one atmosphere, although Battelle has operated a prototype gasifier coupled with a $200 \mathrm{Kw}$ gas turbine with a pressure ratio of 4 . Utilizing existing technologies for biomass gasifiers will force the use of auxiliary compressors to raise the pressure of the gaseous secondary fuel to a level high enough to allow its injection into the gas turbine combustor. This economic penalty tends to drive the choice of gasifier toward those that can produce the highest energy gas possible usually a MEG. The higher the lower heating value of the fuel gas the lower the flow rate required by the engine. The lower the flow rate the smaller the auxiliary gas compressor and the lower its cost. In addition the same recuperator pressure drop arguments used to justify the MEG over the LEG in the selection of the coal gasification systems also applies here.

The most likely of the practical processes to provide the "highest" lower heating value of the secondary gas fuel is pyrolysis. Pyrolysis of biomass (wood) under an atmosphere of its own decomposition products can produce gases that have lower heating values between 380 and 400 Btu/SCF depending on the hydrogen and moisture content of the feedstock. Hydrogasification which is pyrolysis under an atmosphere of hydrogen can produce even higher heating values because of the production of higher hydrocarbons. In comparison oxygen blown gasifiers with the same feed materials typically produce secondary fuels with lower heating values between 280 and $300 \mathrm{Btu} / \mathrm{SCF}$ $\left(10.4\right.$ and $\left.11.2 \mathrm{MJ} / \mathrm{nM}^{3}\right)$. The main problem with pyrolysis type gasifiers is that they produce a char that also contains the mineral matter oiginally present in the feedstock. Essentially the char 
contains the ash associated with the original biomass. This char material has either to be sold as a product or used as the fuel to heat the feed material to a temperature at which the desired pyrolysis reactions take place.

One approach that has been successfully demonstrated on many different biomass materials is the Garrett multiple hearth gasifier. Five separate hearths are used to sequentially accomplish drying, pyrolysis, char combustion (two stages), and ash cooling (or air heating). In this system the char is burned to provide the energy to run the process. The primary product produced is a combustible gas. Byproducts include small quantities of pyrolysis oil and aqueous acetic acid. Waste products include the combustion flue gases, carbon dioxide, hydrogen sulfide, and ash. Other gasifier systems with similar properties have been developed by Texas Tech University (cattle manure), and the Institute of Gas Technology (peat and coal) 


\section{SECTION 3.0}

\section{CONCLUSIONS AND RECOMMENDATIONS}

\subsection{CONCLUSIONS}

1. The main conclusion reached in this study of converting the GFATS into a CFATS is that gasification is probably the only practical approach. The combustion of coal and biomass in a recuperated engine will require the conversion of the solid fuels to secondary gaseous fuels.

2. Two different gasifiers will be required one for coal and a separate gasifier for biomass. A coal gasifier sized for a 5-MW engine by itself based on the data available appears to be not cost effective. The Garret system for the gasification of biomass could possibly be sized small enough that it could supply on a cost effective basis the fuel for a 5-MW engine.

3. During the design of the ATS the external duct sections (to and from the recuperator) will have to be so arranged that they can be easily modified or replaced. This will build-in the conversion capability of the GFATS to a CFATS configuration. The necessary combustion section needed to handle gaseous fuels derived from coal and other biomass substances will be mounted external to the ATS using the available external duct connections

\subsection{RECOMMENDATIONS}

The main recommendation is that further research into a common pressurized gasifier capable of handling both coal and biomass be conducted. A single multifuel capable gasifier will significantly ease the integration and conversion problems faced by gas turbine manufacturers. Such a gasifier should largely be scale independent in that it must be capable of being produced in a number of sizes. 